\title{
The First Record for the Americas of Loxodes rex, a Flagship Ciliate with an Alleged Restricted Biogeography
}

\author{
Hunter N. Hines ${ }^{1,2}$ • Peter J. McCarthy ${ }^{2}$ Genoveva F. Esteban ${ }^{1}$
}

Received: 6 March 2015 / Accepted: 23 July 2015 / Published online: 19 August 2015

(C) The Author(s) 2015. This article is published with open access at Springerlink.com

\begin{abstract}
As the foundations of food webs, protozoa are essential to the success of an ecological system. These organisms are often overlooked, and research in the Americas is sparse. Recent samplings conducted in freshwater canals and ponds in Florida, USA, have revealed Loxodes rex, an alleged endemic ciliate species. Originally described as endemic to tropical Africa, L. rex has been considered a prime candidate for proof of microbial endemism. Our studies have shown this giant, non-encysting ciliate to be thriving in subtropical Florida. Our observations are novel and include both the first record of occurrence for the Americas and the first highquality in vivo images for this charismatic species.
\end{abstract}

Keywords Biogeography $\cdot$ Ciliate $\cdot$ Endemism $\cdot$ Florida . Loxodes rex · Protozoa

\section{Introduction}

Most large animals (e.g., mammals) show restricted biogeographies and endemism. There exists an unknown size range under which all species dispersals are probably ubiquitous (e.g., bacteria). Protists, including the large tropical ciliates,

Genoveva F. Esteban

gesteban@bournemouth.ac.uk

Hunter N. Hines

hunter.n.hines@gmail.com

1 Department of Life and Environmental Sciences, Bournemouth University, Poole, Dorset BH12 5BB, UK

2 Harbor Branch Oceanographic Institute, Florida Atlantic University, Fort Pierce, FL 34946, USA probably lie below this barrier of endemism [1]. If this is the case, wherever the specific environmental parameters for their growth exist, and adequate dispersal time has passed, then any range of ciliates would be found in the system, despite distances of thousands of kilometers between habitats. Microbial populations are so large, and distribution potential at a global level is so prevalent, that protozoan dispersal may not be affected by physical barriers [2,3].

Loxodes rex (Protozoa, Ciliophora, Karyorelictea) is a giant (>1 mm) non-encysting, unicellular eukaryotic organism that actively moves in a freshwater environment as a voracious predator. The beating of ciliary rows enables the cell to seek out its preferred microhabitat within an ecosystem. An organelle unique to the class is the Müller body, a statocyst-like organelle that informs the cell of its position relative to the gravity vector [4].

L. rex has been listed as a flagship species and identified as one of the ultimate proofs for the theory of microbial endemism [5-7]. This ciliate was originally described as endemic to tropical African countries such as Cameroon and Uganda $[8,9]$ but later found thriving in Thailand [10].

\section{Methods}

Water samples were collected from within a $2-\mathrm{km}$ stagnant section of a freshwater canal system in the watershed of the Indian River Lagoon, Florida, USA $\left(27^{\circ} 31^{\prime} 56.3^{\prime \prime} \mathrm{N} 80^{\circ} 23^{\prime}\right.$ $\left.54.1^{\prime \prime} \mathrm{W}\right)$. The canal is $\sim 7 \mathrm{~m}$ wide, at least 50 years old, and has had little if any management after completion. Samples were collected from the bottom layer sediment interface $(\sim 60 \mathrm{~cm})$ of the canal, using a weighted and corked $500-\mathrm{ml}$ glass sample bottle on a line. The samples were taken four times per week during the months of October 2014 to January 2015, with L. rex always being found, often in high densities 
Fig. 1 Loxodes rex, a flagship free-living ciliate species. In vivo image of cells found thriving in Florida, USA, greatly expanding the known biogeographic range (see text for further details). a Oral aperture of L. rex. Scale bar $100 \mu \mathrm{m}$. b Detail of ciliary rows and the line of Müller bodies down the length of cell (see arrow). Scale bar $250 \mu \mathrm{m}$. c Image of swimming cell, showing a large number of ciliary rows diagnostic to the species. Scale bar $250 \mu \mathrm{m}$

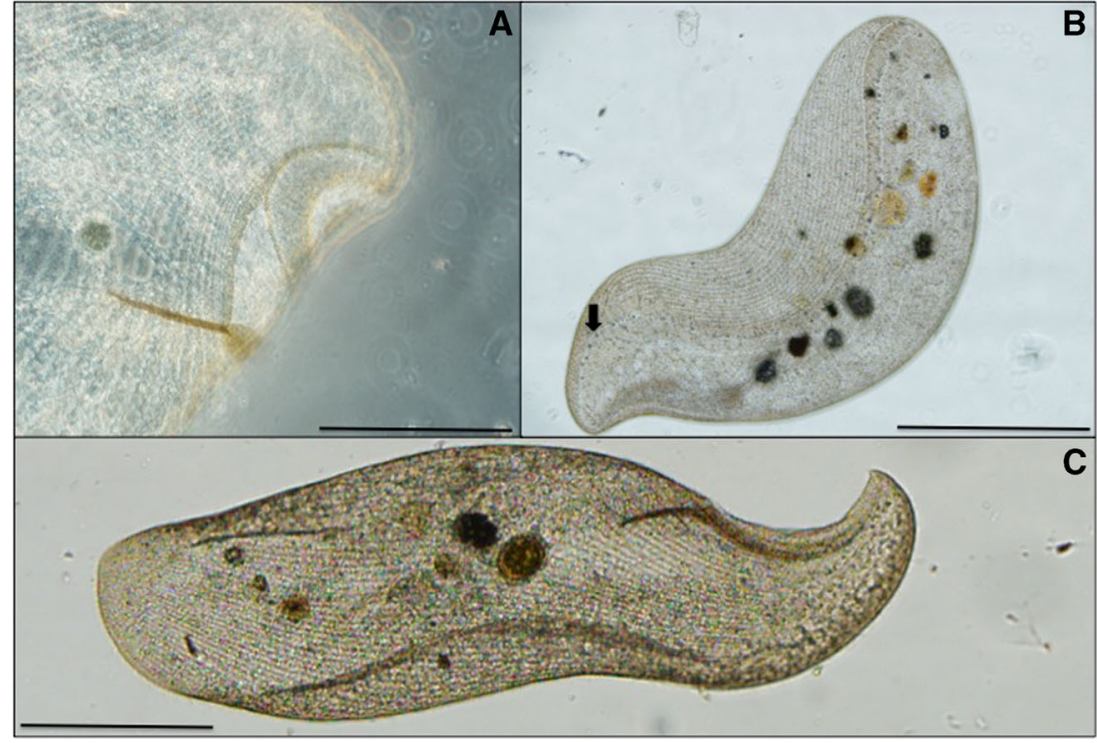

of up to 10 cells per $1-\mathrm{mL}$ subsample. Water temperatures ranged between 21 and $29^{\circ} \mathrm{C}$.

For the identification of further habitat characteristics, a handheld YSI 63 sensor was deployed within the system. Temperature, $\mathrm{pH}$, salinity, and conductivity were obtained at various points throughout the water column in the habitat that contained L. rex. A second device, a ProODO, was used to measure dissolved oxygen content throughout the water column and was tested in several points in the habitat.

Subsamples from the canal water were taken from the bottles using sterile pipets. These were examined within a 1-mL glass Sedgewick-Rafter counting chamber using an Olympus BX-53 light microscope. Cells were further picked and pipetted onto a welled microscope slide for observations of greater detail. Cell measurements were carried out, and digital images were created and analyzed using the Olympus CellSens software package. More than 500 cells were measured. All aspects of this study were performed on living cells.

\section{Results and Discussion}

Initial studies revealed the presence of an abundant ciliate population in the water samples. The giant ciliate observed was flattened, with a concave and anterior oral aperture situated on a rim, forming a beak-like hook so that the ciliate has a clear left and right side (Figs. 1 and 2). The right side is ciliated, with dikinetids arranged in bipolar kineties; the left
Fig. 2 a View of living Loxodes rex. Center vertical lines of the chamber are $1000 \mu \mathrm{m}$ apart. b Open oral aperture (top left) with ciliary row detail. Scale bar $100 \mu \mathrm{m}$. c Swimming L. rex with numerous ciliary rows. Note the row of Müller bodies at the bottom left which runs parallel to the oral aperture. Scale bar $500 \mu \mathrm{m}$. d Image of a dividing cell. The cell at the right is the original cell, and the cell at the left is the newly formed cell, with division area indicated by $X$ 's. Note difference in oral aperture development from complete at the right (large arrow) to new formation at the middle right (small arrow). Scale bar $500 \mu \mathrm{m}$

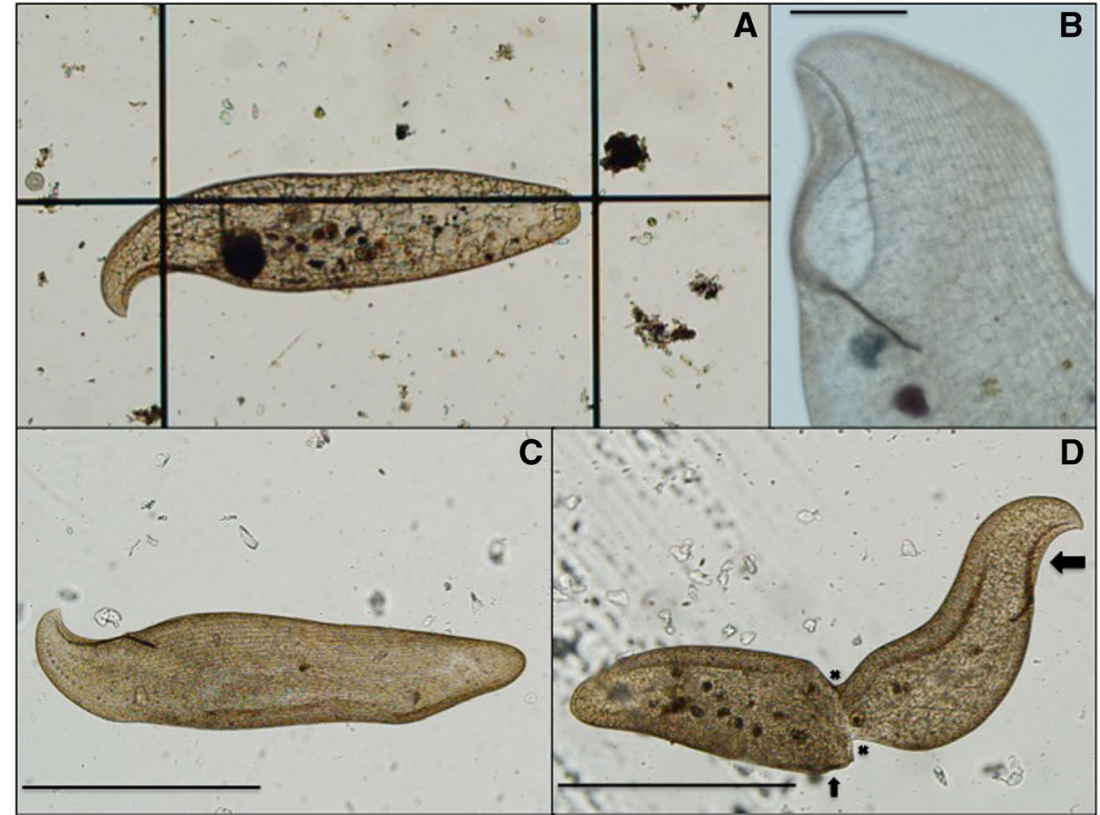


Table 1 Comparison from the literature of original Loxodes rex description from Africa $[8,9]$ with our current findings of $L$. rex in Florida, USA. The strain from Florida is larger, with the largest cell recorded. More than 500 cells were measured for this study

\begin{tabular}{lll}
\hline & Loxodes rex (Africa) & Loxodes rex (Florida) \\
\hline Number of kineties & $79-84$ & $\sim 80$ \\
Number of Müller bodies & $\sim 60$ & $45-60$ \\
Number of macronuclei & $132-181$ (average 150) & $\sim 150$ \\
Number of micronuclei & $39-138$ (average 67) & $\sim 70$ \\
Length range & $500-1200 \mu \mathrm{m}$ & $550-1350 \mu \mathrm{m}$ \\
Length average & $750 \mu \mathrm{m}$ & $835 \mu \mathrm{m}$ \\
Width average & $250 \mu \mathrm{m}$ & $205 \mu \mathrm{m}$ \\
Color & Dark brown & Dark brown \\
\hline
\end{tabular}

side bears only two bipolar kineties, and the posterior end is rounded. The Müller bodies can be found in a lengthwise row down the left side of the cell body starting with $\sim 10$ opposite the oral aperture, with an additional $\sim 40$ throughout the cytoplasm along this line. This is diagnostic to the ciliate L. rex [9] (Table 1).

The YSI devices showed that the $\mathrm{pH}$, conductivity, and temperature varied little from the surface to the bottom $(<60 \mathrm{~cm})$ of the habitat. Values of $\mathrm{pH} 6.6,0.5 \%$ salinity, and $22{ }^{\circ} \mathrm{C}$ were obtained during a normal sample period. Dissolved oxygen content varied dramatically within the vertical system, with the highest values at the surface. The surface zone had levels between 62-65\% dissolved oxygen (DO) saturation and 5.44-5.66 mg/L DO, which was due to the high concentration of aquatic plant life such as Lemnoideae. The bottom zone (where L. rex is found in the greatest numbers) was confirmed to be nearly anoxic; with dissolved oxygen levels between $2.2-2.8 \%$ DO saturation and $0.19-0.24 \mathrm{mg} / \mathrm{L}$.

L. rex was found to thrive in a freshwater, mostly stagnant, canal within the Indian River Lagoon watershed and also three surrounding ponds. Our findings of $L$. rex living in subtropical Florida are novel and significantly expand the global distribution range for this organism. At a distance of over $10,000 \mathrm{~km}$ from the known African habitat range, the Florida L. rex strain indicates that dispersal is not a limiting issue for the species, which probably thrives wherever it finds its preferred ecological habitat.

Although sampled from the oxygen-depleted layers of shallow freshwater systems, the true ecological niche for $L$. rex is not yet known, as the ecosystem present in Florida is analogous to the original African sites. We have found other large ciliates with alleged restricted distributions [5, 9] such as Frontonia vesiculosa in the same Florida site (work in progress).

Our confirmation that L. rex inhabits the oxic/anoxic zone within the water column is consistent with the Loxodes literature, stating the cells prefer a habitat with oxygen tensions between 5 and $10 \%$ [4]. In vivo observations revealed that the species is extremely sensitive to vibrations, with cells rapidly contracting in size after a stimulus. Light level increase also appears to affect $L$. rex swimming behavior, as with other Loxodes species [4].
Further studies of the US populations of this and other large-sized ciliates will enhance our understanding of the potential distribution for ciliate species, and by extrapolation of other microbes, particularly protists. A 3-day cold weather event in South Florida (air temp $\sim{ }^{\circ} \mathrm{C}$ ) caused water temperatures at the study site to drop to $9{ }^{\circ} \mathrm{C}$. Samples were taken throughout this period and revealed that $L$. rex survived, in low population densities, during this cold period. High abundances rapidly recovered in both the habitat and laboratory cultures once temperatures increased to at least $20{ }^{\circ} \mathrm{C}$. The L. rex tolerance range remains unknown, but these initial results suggest that the species can tolerate zones outside of the tropics, thereby expanding its potential global distribution.

The difficulty with which the microbial biome is elucidated from any number of sample areas contributes to the idea that perceived microbial endemism is simply a result of the unexplored - not the nonexistent. As more sites are sampled, more specimens and therefore greater ecological understanding of L. rex can be obtained, including its detailed niche and dispersal potentials. As more habitats are examined, additional so-called "flagship" ciliates will have their biogeographic status expanded and changed.

Acknowledgments This project was funded, in part, by the John Warner Memorial Fund (USA). Support from the Alice Ellen Cooper Dean Charitable Foundation (UK) is also acknowledged. We thank Dr. Brian Lapointe, HBOI, for the use of the YSI and ProODO sensors. We thank Joseph J. Abram and Gabby Barbarite for the figure production assistance. This is Harbor Branch Oceanographic Institute Contribution \#1974.

Open Access This article is distributed under the terms of the Creative Commons Attribution 4.0 International License (http:// creativecommons.org/licenses/by/4.0/), which permits unrestricted use, distribution, and reproduction in any medium, provided you give appropriate credit to the original author(s) and the source, provide a link to the Creative Commons license, and indicate if changes were made.

\section{References}

1. Finlay BJ, Fenchel T (2004) Cosmopolitan metapopulations of free-living microbial eukaryotes. Protist 155:237-244. doi:10. 1078/143446104774199619 
2. Finlay BJ, Esteban GF, Fenchel T (1998) Protozoan diversity: converging estimates of the global number of free-living ciliate species. Protist 149:29-37. doi:10.1016/S1434-4610(98)70007-0

3. Fenchel T, Finlay BJ (2003) Is microbial diversity fundamentally different from biodiversity of larger animals and plants? Eur $\mathrm{J}$ Protistol 39:486-490. doi:10.1078/0932-4739-00025

4. Fenchel T, Finlay BJ (1986) The structure and function of the Müller vesicles in Loxodid ciliates. J Protozool 33:69-76. doi:10. 1111/j.1550-7408.1986.tb05560.x

5. Foissner W (2006) Biogeography and dispersal of micro-organisms: a review emphasizing protists. Acta Protozool 45:111-136

6. Foissner W, Chao A, Katz L (2008) Diversity and geographic distributions of ciliates (Protista: Ciliophora). Biodiver Conserv 17: 345-363. doi:10.1007/s10531-007-9254-7
7. Fontaneto D (2011) Biogeography of microscopic organisms. Systematics Association special volume. Cambridge University Press, England. ISBN 978-0-521-76670-8

8. Dragesco J (1970) Ciliés libres du Cameroun. Ann Fac Sci Yaoundé (Hors série): 1-141.

9. Dragesco J, Dragesco-Kernéis A (1986) Ciliés libres de l'Afrique intertropicale. Introduction à la connaissance et à létude des Ciliés. Editions de l'Orstom Faune Tropical XXVI, Paris. ISBN 2-7099. 0750-X

10. Esteban GF, Finlay BJ, Charubhun B, Charubhun N (2001) On the geographic distribution of Loxodes rex (Protozoa, Ciliophora) and other alleged endemic species of ciliates. J Zoology 255:139-143. doi:10.1017/ S0952836901001200 